Portland State University

PDXScholar

Electrical and Computer Engineering Faculty

Publications and Presentations

3-7-2019

\title{
Challenges in Designing a Mentorship Program for Electrical Engineering Freshmen
}

\author{
Branimir Pejcinovic \\ Portland State University, pejcinb@pdx.edu \\ Melinda Holtzman \\ Portland State University, holtzman@pdx.edu
}

Follow this and additional works at: https://pdxscholar.library.pdx.edu/ece_fac

Part of the Electrical and Computer Engineering Commons

Let us know how access to this document benefits you.

\section{Citation Details}

B. Pejcinovic and M. Holtzman, "Challenges in Designing a Mentorship Program for Electrical Engineering Freshmen," 2018 IEEE Frontiers in Education Conference (FIE), San Jose, CA, USA, 2018, pp. 1-5.

This Post-Print is brought to you for free and open access. It has been accepted for inclusion in Electrical and Computer Engineering Faculty Publications and Presentations by an authorized administrator of PDXScholar. Please contact us if we can make this document more accessible: pdxscholar@pdx.edu. 


\title{
Challenges in Designing a Mentorship Program for Electrical Engineering Freshmen
}

\author{
Branimir Pejcinovic and Melinda Holtzman \\ Electrical and Computer Engineering Department \\ Portland State University \\ Portland, OR \\ pejcinb@pdx.edu, holtzman@pdx.edu
}

\begin{abstract}
This Work in Progress Innovative Practice Paper addresses three challenges we face when teaching freshmen: a) how to present a wide variety of sub-fields in electrical engineering, b) how to establish the relevance of electrical engineering to things they care about, and c) how to relate electrical engineering to students' experiences. We are attempting to address these through a mentorship program involving recent alumni working with teams of freshman electrical engineering students. Mentors are expected to: (i) come to class and speak about their job experience, (ii) meet with their teams early in the term to help them get started with their projects, (iii) provide a mock job or internship description to which the students apply by providing resumes and cover letters, (iv) giving feedback on their mock applications, and (v) be available by email or other means to answer questions throughout the quarter. While mentors were enthusiastic, some student teams were not as engaged as we had expected. Mentors suggested keeping students more accountable. Students were more concerned about more structured meetings with mentors and having clear expectations. We agree with these suggestions and are working on their implementation. Overall, our initial results are encouraging enough for us to continue developing this program further.
\end{abstract}

Keywords-mentorship, freshmen engineering

\section{INTRODUCTION ANDBACKGROUND}

The student experience during the freshman year has been recognized as one of the keys to not only attracting more students into engineering and improving retention, but also to forming some significant attributes of successfulengineering graduates [1]. Portland State University is an urban university, and its Electrical and Computer Engineering (ECE)

department serves a relatively large and very diverse student population including a large fraction of transfer and part-time students. We redesigned our freshman year roughly 10 years ago, as explained in [2]. We decided to offer three freshman ECE-oriented classes immediately instead of general classes designed to cover all the traditional engineering disciplines as in the earlier college-taught course. The first one-ECE 101 Exploring Electrical Engineering - was meant to be the gateway into the ECE program, one that would be more inviting to students. Instead of trying to filter them out of the program, we would present them with a spectrum of engineering challenges that are fun to work on [3]. We also wanted to make our program more attractive to undecided and traditionally under-represented groups of students. Given that active student learning in the form of hands-on projects and lab-based approaches are very effective [4]-[6], we designed the three freshman courses with this in mind.

There are many challenges to teaching ECE 101. For example, concerns about students' math preparation and problem-solving skills have been reported previously [7]. A large (typically about 80 students) diverse class will contain students of various ages and experience, from a few traditional freshmen straight out of high school to those who are working and with families of their own. Roughly half of our students work part or full-time. Some students are already familiar with the engineering profession, but many have little idea of the range of job opportunities available within the broad category of electrical engineering, and what those jobs actually entail.

An interesting approach to addressing some of these is sues was presented by Ott [8] where freshman CS students were asked to maintain email contact with their industry mentor and were given a set of specific tasks to complete. We liked the exploratory nature of this approach but thought that face-toface interaction would be even better. We also have a very effective capstone program [9] where students work with industry mentors, so we could potentially build on our experiences in running that program. The particular challenges addressed in this paper are:

1. how to introduce students to the wide variety of subfields in electrical engineering,

2. how to establish the relevance of electrical engineering to things that students care about, and

3. how to relate electrical engineering to students' experiences.

The last two items relate to student motivation, which we hope will lead to the development of intrinsic motivation. Motivation is well known to relate to success and retention, e.g. [10]. Within the self-determination framework, there are three factors that lead to a sense of intrinsic motivation: feelings of autonomy, competence, and relatedness [11],[12]. Our approach to mentorship primarily addresses relatedness, 
but other components of the course are designed to address the other two factors as well. For example, by allowing students to select their projects we enhance their sense of autonomy.

Next, we discuss the course design and implementation of the mentorship program, followed by some initial observations and data.

\section{COURSE DESCRIPTION}

By the end of the ECE 101 course students are expected to have attained these learning outcomes:

1. Solve engineering problems

2. Perform research on areas of electrical engineering

3. Write technical reports and summaries

4. Perform simple lab experiments

5. Complete a project involving both design and technical elements

6. Work on a team

The class meets for two 90-minute lectures and one three-hour lab each week over a 10 -week quarter. In the lecture class, speakers from both the faculty and local industry present an overview of different fields and career opportunities in electrical engineering. Some basic technical content such as simple circuits and logic gates is introduced, and we have lately been adding more math review. There are presentations and class activities on communication, ethics, teamwork and project management and design.

Students first do a short "mini-project" to help teams learn to work together, then a larger project for the rest of the term. Students work in teams of four to six. For the larger project, they have a choice of a Rube Goldberg machine with some electrical elements, or they can propose a project of their own choice. Students generally find the project creative and fun. Teams demonstrate their project and submit a final report at the end of the term.

In the lab, students are introduced to building circuits on breadboards, and to basic lab bench equipment such as a DC power supply, multimeter, function generator and oscillos cope. They are also introduced to the software programs LTSpice and MATLAB. All the labs are fairly simple, but we believe being exposed to the lab environment in a slower-paced, non-threatening introductory course will make the more rigorous labs they experience in later classes less intimidating.

\section{THE MENT ORSHIP PROGRAM}

In the Fall 2016 term, we started a program to involve recent alumni working in local industry as mentors in ECE
101. We contacted graduates of our department still working in the Portland area, and asked them to volunteer as mentors in the class. One mentor was assigned to each team, and the mentors were asked to do several things. First, they were asked to talk about their job experience. This could be each mentor talking to their own team, or a panel of mentors all presenting to the class as a whole, depending on how the individual instructor arranged it. Second, mentors provide a realistic job or internship description to which the students "apply" by submitting resumes and cover letters. The mentors then give feedback on the students' applications. Third, mentors meet with their teams in-pers on at least once, but ideally two or three times, throughout in the term to help students with their projects. This could involve giving feedback on project ideas, discussing any teamwork or organizational issues, and reviewing the project proposal and report. More than just technical project assistance, these meetings are meant to provide a chance for students to make a personal connection with a working professional in their field.

We have tried to minimize the time commitment for the mentors in the hope of attracting a sufficient number, given that more than a dozen are needed each term. Below is an outline of typical mentor-team interactions over a 10 -week term.

Week 2: mentors as signed and email given to students Week 3: teams collectively contact mentor and set up meeting

Week 4: get acquainted; mentor discus ses career, work environment, etc.; discuss student project plans

Week 5: teams present draft of their project

Week 6: further discussion of the project; resumes given to mentor

Weeks 7 \& 8: mentor gives feedback on resumes; teams update mentor on their project progress

Week 10: if possible, mentor comes for final project demo

\section{MENTORSHIP PROGRAM RESULTS}

Overall, mentors involved in the program have been happy to be involved. Many alumni are eager to give back and share their experiences with other students. There was wide variation in the amount of interaction, however, stemming primarily from job and time constraints. Some mentors took students for company on-site visits, while others had to communicate remotely due to unexpected travel and other commitments.

The students have not been as eager as we had hoped they would be. Students seem happy to meet the mentors when they come to class, but they are reluctant to reach out to the mentors with email questions or to request additional meetings. Most submitted resumes and coverletters when it 
was made a graded homework assignment, but few participated in the exercise when it was optional.

\section{A. Student Survey}

To get more feedback on the course and student learning we have been administering an end-of-term survey dealing with students' as sessment of their own learning, i.e., their selfefficacy. This part of the survey consis ts of seven multiple choice questions and utilizes a five-point Likert-like scale from Strongly Agree to Strongly Disagree. In addition, we also ask students which of the eight components of the course they find most helpful for their learning. This is also scored on five-point scale from Very Helpful to Complete Waste of Time. To gather student feedback regarding the mentor program, in Fall 2017 we added the open-ended question "Comment on your interaction with team mentor and how we may improve it." Based on the collected comments, we intend to add another multiple-choice section about the mentorship program in future surveys.

Three questions from this survey are given in Table I which address student self-efficacy with respect to parts of their projects, such as working on a team or defining a project management plan. These three were selected to include here because these are the parts that mentors worked on with students

T ABLE I. MEAN SCORESON ST UDENT SURVEY REGARDING THEIR CONFIDENCE IN THEIR ABILITY TO PERFORM SOME PROJECT -RELATEDTASKS.

\begin{tabular}{|l|c|c|}
\hline \multicolumn{1}{|c|}{ Task } & Mid-Term & $\begin{array}{c}\text { End of } \\
\text { term }\end{array}$ \\
\hline $\begin{array}{l}\text { complete a project involving } \\
\text { design and technical elements }\end{array}$ & $4.03^{*}$ & 4.11 \\
\hline work on a team & 4.18 & 4.33 \\
\hline $\begin{array}{l}\text { define and implement project } \\
\text { management plan }\end{array}$ & 3.9 & 4.11 \\
\hline
\end{tabular}

${ }^{*} 1$ = Strongly Disagree, 5 = Strongly Agree

The survey was administered twice: half-way through the course, and a second time after the final exam. The initial midterm survey happened around the time when student teams started interacting with their mentors. To avoid survey fatigue, for the $2^{\text {nd }}$ survey we encouraged only students who did not take the first one to take it. The higher numbers for the second set, even though they are different students, do on average reflect an increase in student confidence by the end of the course.

In the comments section, students were asked to comment on their interaction with mentors. To help with the analysis we categorized comments into a) mostly positive, b) mixed, and c) mostly negative. There were 67 enrolled students; 40 took the mid-term survey and 28 of these provided comments on mentor interactions. A further 17 took the survey at the end of term and 13 of these provided comments. Obviously, the latter group is more relevant regarding the effectiveness of our mentorship program, but the mid-term results can be used to detect any implementation problems.

Of the first 28, we would categorize 12 as mostly positive, characterized by comments such as "good interaction" or "very helpful". Another 14 either didn't comment on the interaction (i.e., they only made suggestions forimprovement) or they gave what we considered a mixed response, part positive and part negative. For example, they found the first meeting interesting, but subsequent meetings unhelpful, or they had a good email exchange, but were frustrated by being unable to arrange a face-to-face meeting. Lastly, two comments described the interactions as either confusing or unnecessary, which we considered mostly negative.

In the end of the term survey, eight of 13 comments were mostly positive, with comments like "Team mentor really helped to enforce concept of project management $\&$ its importance" and "Awesome, they were very helpful!" The remaining five were mixed, and none of the comments were negative.

Suggestions from students generally fell into two categories:

1. better defining of the mentor role, expectations and responsibilities, and

2. more meetings, and help with scheduling meetings.

\section{B. Mentor Survey}

Only four of the 14 mentors responded to a five-question survey. The results are diverse and the sample is small, but the answers and comments are still informative. The responses are summarized in Table II below. To the statement on student engagement, one mentor commented that engagement varied among the members of the team. Another noted that engagement was strong at the beginning but fell off at the end. Mentors were also asked the number of meetings they had with their teams: two had one meeting, two had three meetings.

During a debriefing meeting after the Fall 2017 term, mentors made the following suggestions:

1. Mentors could work with students while they are deciding on what to do for their final project

2. Have mentors work with students on some kind of "risk assessment" table for their project - will it be finished on time, how cool is it, cost, what are individual team members' background, etc.

3. Have students work on project steps needed along the way 
4. Instructor could tell students to document their thinking on Trello (a collaborative project organization tool [13])

5. Find ways to make students more accountable for interactions with mentor but also in class

T ABLE II. MENT OR SURVEY RESULTS

\begin{tabular}{|c|c|c|c|c|}
\hline $\begin{array}{c}\text { Strongly } \\
\text { agree }\end{array}$ & Agree & Neutral & Disagree & $\begin{array}{c}\text { Strongly } \\
\text { disagree }\end{array}$ \\
\hline \multicolumn{5}{|c|}{ 1. Students were very much engaged } \\
\hline 1 & & 2 & & 1 \\
\hline 2. Providing more specific deadlines and tasks would be helpful \\
\hline & 1 & 2 & & 1 \\
\hline 3. Having student produce CV and cover letter is useful and \\
appropriate at this stage
\end{tabular}

The overall response from the mentors, both from written comments and discussion, was that students needed to be more responsible and accountable, setting tasks and deadlines for themselves. Mentors can help with this but should not set the tasks for the students.

\section{DISCUSSION AND CONCLUSIONS}

Overall, while many students seemed to enjoy interacting with their mentors and found them helpful, they were not as engaged with their mentors as we hoped they would be. In general, students seemed intrigued by the idea at first, and most seemed engaged when meeting their mentors for the first time. But the program did not maintain momentum, and engagement and satisfaction decreased. Students were frustrated when they had difficulty scheduling in-person meetings with their mentors, and many were not clear on just what the mentors were supposed to be doing. The benefits of networking, of understanding the day-to-day life of an engineer, and of having a valuable industry connection for the future were not clear.

Students who took the effectiveness survey at the end of the quarter did report increased confidence in their abilities to complete projects, work on teams and define and implement a project management plan, all things the mentor helped with. While this is a promising indication, it is not direct evidence that the mentors are responsible. Comments from students who took the survey at the end of the quarter were more positive (62\%) than those who took it mid-way (43\%). In the next academic year (Fall 2018) the survey will have multiple- choice questions directly asking about the mentor program, and we will have more quantitative data.

We collected feedback from seven out of 14 mentors, through a survey and discussions. Mentors initially expressed great excitement and eagerness to take part in the program and to share their enthusiasmand experience with freshman. In the survey, mentor responses to specific questions varied widely. The overall impression though is that they did not get the engagement from students we all had hoped for. They mostly agreed that students need stronger project management skills to handle a term-long project, such as breaking down tasks, creating a schedule and meeting milestones. However, we believe it would not be beneficial for mentors to do this for students, but that students need to learn these skills for themselves, with mentor guidance.

We strongly believe that this program still has great potential, but that we need to make some improvements to increase the engagement of and benefit to students. Some ideas we are trying this year include having

1. mentors commit to at least two face-to-face meetings,

2. mentors help students set up a project plan and schedule and

3. students check in weekly with their mentor via email or other platform with a status report and questions.

Other improvements in future work include increasing the sample size for both student and mentor feedback in order to obtain more statistically significant data, and revise survey questions to betteraddress the mentoring program and its objectives specifically. We also need to better relate the mentor program tasks, such as the job application assignment, to the course outcomes, with the aim of improving student motivation.

We believe that students have much to gain from the personal interaction with a young professionalengineer, and we hope to continue to improve the program. We hope students will come to appreciate the benefits of having an industry contact and the valuable advice and feedback being provided.

\section{REFERENCES}

[1] J. Spurlin, S.A. Rajala, and J.P. Lavelle, ed. "Designing Better Engineering Education Through Assessment: A Practical Resource for Faculty and Department Chairs on Using Assessment and ABET Criteria to Improve Student Leaming," chapter 8, pp. 213-245, Stylus Publishing, 2008.

[2] P.K. Wong. M. Holtzman, B. Pejcinovic, M. Chrzanowska-Jeske, "Redesign of freshman electrical engineering courses for improved motivation and early introduction of design," in 2011 ASEE Annu. Conf. and Expo., Vancouver, BC, 2011,pp. 22.1224 .1 - 22.1224.13.

[3] D.W. Knight, L.E. Carlson, and J.F. Sullivan, “Improving Engineering Student Retention through Hands-On, Team-Based, First-Year Design 
Projects," ASEE 31 st Intl Conf on Research in Engineering Education, 2007.

[4] M.J. Prince and R.M. Felder, "Inductive Teaching and Learning Methods: Definitions, Comparisons, and Research Bases," J. Engineering Education, vol. 95, no. 2, pp. 123-138, 2006.

[5] J. Richardson, et.al., "Freshman Design Projects in the Foundation Coalition," [Online] Available: http://www.foundationcoalition.org/ publications/journalpapers/AuthorHTML/R.htm

[6] J. Froyd, A. Srinivasa, D. Maxwell, A. Conkey, and K. Shryock, "A Project-Based Approach To First-Year Engineering Curriculum Development," in Proceedings Frontiers in Education 35th Annual Conference, 2005, pp. T3H-T3H.

[7] B. Pejcinovic, M. Holtzman, P.K. Wong, G. Recktenwald, “Assessing Student Preparedness for Introductory Engineering and Programming Courses" in Proceedings Frontiers in Education Conference, 2017, DOI: 10.1109/FIE.2017.8190539.

[8] L. Ott, "Alumni as a resource to increase student retention in early computer science courses," in IEEE Frontiers in Education Conference (FIE), 2015.32614 2015. DOI: 10.1109/FIE.2015.7344025.

[9] M. Faust, A. Greenberg, and B. Pejcinovic, "Redesign of senior capstone program in electrical and computer engineering and its assessment," in 2012 Frontiers in Education Conference Proceedings, 2012, pp. 1-6.

[10] B. F. French, J. C. Immekus, and W. C. Oakes, “An examination of indicators of engineering students' success and persistence," Journal of Engineering Education, vol. 94, no. 4,pp.419-425, 2005.

[11] E. L. Deci and R. M. Ryan, "The "what" and "why" of goal pursuits: Human needs and the self-determination of behavior," Psychological inquiry, vol. 11, no. 4, pp. 227-268, 2000.

[12] R. M. Ryan and E. L. Deci, "Self-determination theory and the facilitation of intrinsic motivation, social development, and well-being," American Psychologist, 55(1):68-78, 2000.

[13] [Online] Available: http://trello.com. Last accessed on July 7, 2018. 